\title{
An Empirical Study of Factors Influencing Consumers' Purchasing Behaviours in Shopping Malls
}

\author{
Mandy Mok Kim Man ${ }^{1} \&$ Ricky Cai Qian Qiu \\ ${ }^{1}$ University of Reading Malaysia, Malaysia \\ ${ }^{2}$ Nilai University, Malaysia \\ Correspondence: Mandy Mok Kim Man, University of Reading Malaysia, Malaysia. E-mail: \\ k.mok@henley.edu.my
}

Received: October 2, 2020 Accepted: November 4, 2020 Online Published: January 10, 2021

doi:10.5539/ijms.v13n1p14 URL: https://doi.org/10.5539/ijms.v13n1p14

\begin{abstract}
Since a couple of years ago, the development of shopping malls is booming in the Klang Valley-Kuala Lumpur area in Malaysia. Motivating consumers for frequent visits to shopping complexes is imperative in order to run a successful shopping mall in such a competitive retail environment like the Klang Valley-Kuala Lumpur with over 100 shopping plazas. Getting knowledge of the elements attracting consumers to visit a shopping mall and make purchases is of greatest importance in order to achieve high profit return and increase economic growth and development of a nation. The objective of this research paper is to study the factors influencing the consumers' buying behaviours in the shopping malls. The environmental related factors (building structure, atmosphere, sounds and music and fragrance and smell), services related factors (personal services, price, advertising and promotion), administrative related factors (tenant mix, anchor tenant, entertainments) as well as transportation and location related factors (parking, location, accessibility) were identified as independent variables and consumer's buying behaviour within the malls as a dependent variable. A research framework was developed based on a thorough literature review. There were 200 responses collected from consumers in four shopping malls in Klang Valley-Kuala Lumpur area. Correlation and multiple regression analyses were carried out using the SPSS software package to obtain the results.

The results of this research indicate that environmental, transportation and location related factors have significant impact on consumers' buying behaviours in the shopping malls. The results congruent with previous studies by Brengman et al. (2012) and Grimmer et al. (2016) that indicated that environmental related factors have positive effects on consumers' purchase behaviours. Additionally, this study also found that transportation and location related factors have significant relationship with consumers' purchase behaviours as mentioned by Saber et al. (2017) and Samiran et al. (2015). The findings can be adopted by the shopping malls' managers to improve overall shopping malls' performance as well as by mall developers to evaluate the mall site's location and construction designs. For academicians, this study could be used as a ground work for further exploration of the possibilities to influence consumers' purchase behaviours through different marketing strategies to increase sales and profits.
\end{abstract}

Keywords: customers' behaviours, shopping malls, environmental, services, administrative related factors

\section{Introduction}

The concept of malls is nowadays globally established, rooting from the ancient market places, where people came together from close and far to choose and buy goods and services from traders, farmers and manufacturers living and working there. These ancient markets were not a mere trading place, but also a place for interaction from all parts of a society, also in terms of social, cultural and economic matters (Chebat et al., 2010; Kamel et al., 2013).

The uprising of shopping malls had a tremendous impact on the shopping behaviours of customers. The convenience to easily hop from a retail shop to another retail shop in a comfortable, covered environment, has led to a huge preference of consumers for shopping malls over the hassle of visiting single, not connected shops, having the inconvenience to reach them one by one in different locations (Makgopa, 2016).

The consumers' preference of a shopping mall depends on various factors, such as location, variety of shops and 
services, convenience and entertainment, as well as other social factors, such as family outing, meeting friends or just self-entertainment, like window-shopping or socializing with other visitors (Badar \& Irfan, 2018). All these elements have an impact on the choice of the consumers in deciding which mall to be preferred or avoided. The management of the malls is aware of this and puts every effort into improving their ambience and services in order to meet the visitors' expectations. Preferences of visitors may vary depending on the regional social environment and shopping attitude (Badar \& Irfan, 2018). The researchers can focus on the visitor's perception, their expectations and shopping behaviors and contemplate possible changes within a mall and its impact on the success and profitability of a mall in a survey-based form.

The purpose of this research is to create an instrument for developers and the mall management to enhance and "fine-tune" the performance of their unit in order to achieve the best result in this highly competitive market segment in Malaysia.

This study aims to achieve the following objectives:

1) To identify the environmental, services, administrative, transportation and location related factors that may affect the consumers' purchasing behaviours in shopping malls.

2) To suggest some solutions or strategies that can be implemented in order to overcome the obstacles that are present in the management and marketing processes practiced by shopping malls.

\section{Literature Review on Key Variables}

This section reviews on the key variables for this study, namely consumer purchase behaviours in shopping malls as dependent variable, and environmental, services, administrative and transportation and location as independent variables.

\subsection{Consumers' Purchase Behaviours in Shopping Malls}

The marketing theory and consumer behaviour theory are the two main underlying theories for this research. The marketing theory mentioned that manufacturers and marketers need to produce quality products and/or services to consumers, target the consumers and communicates to them the value of the products and/or services to convince them to purchase and repeat purchase these products and/or services, in order to make profit for the companies and at the same time satisfied the consumers' expectations. More than that, some companies involve in corporate social responsibilities activities (CSR) and give return to society with the profit they gained from the consumers. To obtain support from consumers to purchase their products and/or services, they need to study how consumers behave, such as consumers' preferences, tastes, likes and dislikes, life styles, needs and wants, demographical and psychological factors, political and economic, social cultural factors etc. Furthermore, in the globalization markets, place and location to access the products and/or services has changed to unlimited times and borders for consumers to purchase/use these products and/or services due to the online marketing and digital marketing trends. Therefore, the research to study why consumers go and shop in shopping malls and how to make shopping malls more attractive to consumers becomes relatively important to look in depth the reasons behind.

According to Bijandi and Sadeghi (2011), visitors and customers expect enjoyable shopping process and social experience from a mall. The recent study by Cathy et al. (2020) stated that the presence of multiple facilities around the shops and service outlets within a single location is a crucial factor for visitors to choose a mall over single shops along the streets. Facilities, such as, washrooms, shelters from heat and rain, food courts, free transports to the nearest public transport hubs, taxi-stands in front of the entrance, sometimes children's playgrounds and rest areas. In short, a mall attempts to offer a whole social ambient with few necessities left unserved. This all-in-one comfort concept may lead to the situation where, visitors come to a mall merely to enjoy, the comfort rather than to intend to make a real purchase (Katrodia et al., 2018).

2.2 Environmental Related Factors (building structure, atmosphere, sounds and music, fragrance and smell)

The list of environmental related factors is comprised mainly of the building architecture, the individual atmosphere, sound or music (sometimes combined) and the fragrance and smell within the premises.

According to Bilgehan and Cihangir (2017), the architecture of a shopping complex influences the visitor's buying behaviour significantly. Mariri and Chipunza (2009) said that an appealing design can generate excitement among the visitors and invites them to stay longer or even entices them to make a purchase. It lifts up the mood and give visitors a relaxed and positive feeling.

A mall's own atmosphere is regarded as one of the most important factors influencing the visitors' and shoppers' consumer behaviours. A cosy and unique atmosphere has a positive influence on the visitors' mood and 
encourage them to stay longer and visit more places within the complex. Such positive feeling will result in more shop visits and purchases in the end (Breugelmans \& Campo, 2011).

Irena (2011) stated that sound is nowadays regarded as an important tool for customer entertainment and care. Sound in the form of spoken language and music helps a shop to impart on its merchandise some unique characters to otherwise very similar merchandise available in other shops such that customers and visitors would have an additional element to distinguish the shop's merchandise from similar products elsewhere.

A highly underestimated feature in the overall atmosphere of a shopping complex is the sense of smell (Michon $\&$ Chebat, 2003). This sense of smell has a huge impact of the subconscious of humans and therefore can be a decisive factor in making consumers like or dislike a place or a product. Kumar and John (2014) stated that suitable fragrance notes can be also used in the retail shops and service outlets to give visitors and customers a pleasant impression that help enhance duration of their stay and support their purchase. Based on the literature review, the following hypothesis is postulated:

H1: Environmental factors, which include building structure, atmosphere, sounds and music and fragrance and smell, have a positive relationship towards consumers' buying behaviours within shopping malls.

2.3 Services Related Factors (personal service, price, advertising and promotion)

The services related factors consist of personal service, price, advertising and promotion.

According to Chebat et al. (2010), personal service plays a fundamental role in customer's choice, which shop to choose for a purchase. Apart from the study by Farrag et al. (2010), that found that environmental elements influence the shopper's behaviours, the service provided by the respective staff during a shopper's visit can also affect the shopper's purchase inside the shop. Several criteria define the evaluation of services by customers. They include courtesy and helpfulness of the employees or sales representatives, provision of immediate attention, level of knowledge and sense responsibilities carried by the staff. Receiving an attentive and qualified service during a visit in an outlet strongly influences the mood of a visitor, and has a strong impact on the shopping behaviours (Gudonaviciene \& Alijosiene, 2013).

Price may be a decisive factor, but not in every case. While customers tend to look for the best price, when given a choice between identical products in different outlets, the final choice may not always go to the cheapest option. Cheap price is often paired with low quality in the mind of shoppers, and good quality, even at a higher price, can be a strong influencing factor in a purchase process. Some shoppers also feel valued by purchasing branded or exclusive products regardless of the price level (Farrag et al., 2010).

Promotions, either seasonal or triggered by other events, usually lead to higher number of visitors and an increase of sales, even though the sale may not automatically contribute to a higher profit due to reduced profit margins caused by offering cheaper prices or services. If a promotion only depends on discounts, the effect may be limited (Familmaleki et al., 2015). Promotions like free gifts, lucky draws and performances also please shopping malls' visitors and lead to a higher visit frequency in the shopping complexes (Ashraf et al., 2014). The following hypothesis is drawn based on the literature review.

$\mathrm{H} 2$ : Services related factors, which are comprised of personal services, price, advertising and promotion, have a positive relationship towards consumers' buying behaviours within shopping malls.

\subsection{Administrative Related Factors (tenant mix, anchor tenant, entertainment)}

This research also looks into administrative related factors that consist of tenant mix, anchor tenant, entertainment.

According to Hui et al. (2013), the core to every shopping complex is the variety of merchant shops and service outlets. It is the very reason for the existence of malls (Maher et al., 2019). Visitors expect a wide variety of goods and products as well as service facilities. In addition, all kind of food and drink outlets as well as entertainment units are expected, and they are highly valued as one of the main reasons to visit the mall. Besides, the tenants and their product and service offerings, based on Hung and Sherry (2012), the mall itself is regarded as an outing destination for the whole family, and as a socializing meeting point for friends, colleagues, school and study mates, and also as a source of many other activities.

An anchor tenant determines to a large extent about the image and value of the whole shopping complex. It sets the level of reputation for the whole complex, as an anchor tenant guarantees influx of the bulk of visitors and has a major influence on the composition of the social and economic strata of the crowd. Therefore, an anchor tenant has a considerable impact on smaller tenant units in deciding which mall to join as they mull over which anchor tenant suits them the most. Consequently, this has a massive influence on the level of rental prices the 
mall management would set for its shop lots. In short, an anchor tenant is crucial for the acceptance of the mall by its visitors and influences the frequency of the visitors and their buying behaviours (Hung \& Sherry, 2012).

The success of a shopping complex cannot be derived from its function as a mere shopping place. The level of acceptance and popularity of a mall is determined by additional features. For instance, the mall can function as a social meeting point (Mehvish, 2012). Entertainments providers like a cinema complex, an amusement area and even an ice-skating rink can boost the popularity of a shopping mall massively (Birch \& Sit, 2014). Those services support visitor loyalty and boost the visitors' recognition of the mall as a favourite place to spend their free time. Based on the literature review, the following hypothesis is being put forward.

H3: Administrative related factors comprised of tenant mix, anchor tenant and entertainment, have a positive relationship on consumers' buying behaviours within shopping malls.

2.5 Transportation and Location Related Factors (parking, catchment area and accessibility)

This study also examines transportation and location related factors which consist of parking, catchment area as well as accessibility.

Hanzaee and Javanbakht (2013) stated that the parking zone is a much more influential space on visitor's impression of the whole shopping complex than expected. Because shopping malls are nowadays not only in the city center, but also often in the suburbs or peripheries of an urban agglomeration, access to public transportation is often inadequate or not available at shopping malls. In addition, shoppers tend to acquire their daily needs at the anchor tenant of the mall, so usually a variety of goods has to be transported within the mall and out to the parking area to reach the vehicles that the visitors used to reach the mall's premises.

Location is regarded as the site where the mall can derive its visitor, both the neighbourhood of the mall and the areas that are reasonable distance away from the mall. On the other hand, from the perspective of the visitors, location means a site that is short ways from where the visitors are, has time-saving access for the visitors and provides the visitors the opportunity to be able to obtain everything they need under one roof. In contrast, shopping experience with single shop lots along streets would require making many stops at different locations. (Astono, 2014).

A mall must be easily reachable. Thus, accessibility is a requirement that needs to be fulfilled at the very early stage of planning of a complex mall structure planning (Sebastian, 2015). There are two elements that concern accessibility. One is the macro accessibility, which stands in the way between the visitors and the complex, such as road connections and traffic flow. The other factor is the micro accessibility, which is related to the circulation of movements within the mall itself. Therefore, careful planning ahead of the actual construction of the mall is very important to attract visitors. Based on the literature review, the following is postulated as the hypothesis $\mathrm{H} 4$.

H4: Transportation and location related factors, which consists of parking, catchment area and accessibility, have positive influences on consumers' buying behaviours within shopping malls.

The framework of the current research is shown in Figure 1 below. 


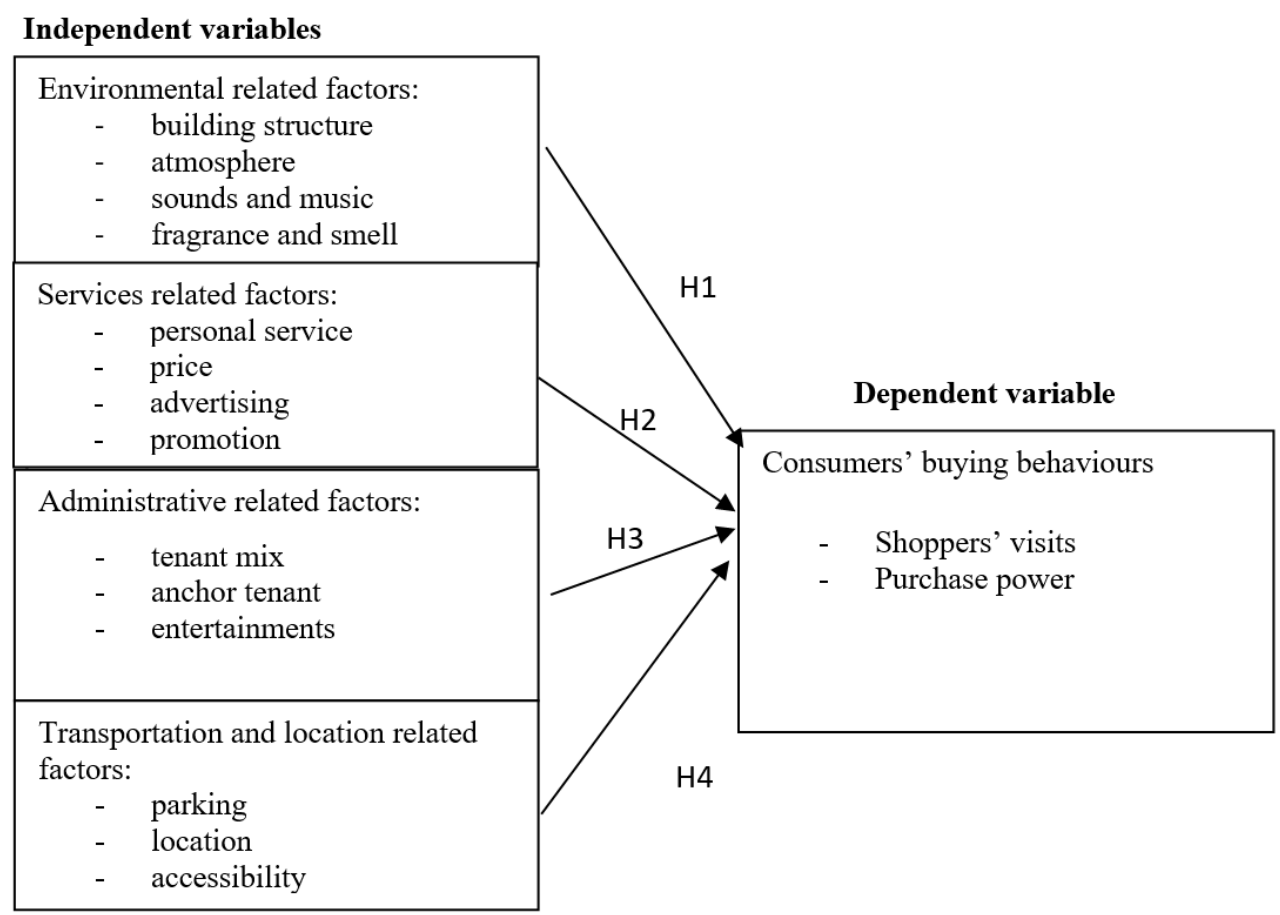

Figure 1. Research framework

\section{Methodology}

Non-probability sampling technique was applied to conduct this research. This research uses quantitative approach and survey questionnaires to collect data. Survey questionnaires were designed to be handed out to respondents in the select shopping malls. Four shopping malls were selected in the Klang Valley-Kuala Lumpur area, namely, Suria KLCC (Kuala Lumpur) Pavillion (Bukit Bintang), Sunway Pyramid (Petaling Jaya) and the Mines Shopping Mall (Seri Kembangan). Prior to data collection, a pilot study was conducted with 25 respondents who were selected randomly from the selected shopping malls and five respondents who are the expert in the subject matter, and tested their understanding of the questionnaires.

The questionnaires consisted of 31 items, where six items were about demographic information of the respondents, twenty items enquired about independent variables and five items about dependent variable. Research questionnaire were distributed by hand and in person by the authors to the consumers in the selected shopping malls and collected immediately after the respondents had filled out the questionnaires. A total of 240 questionnaires were collected from the selected shopping malls. After the data screening process, 200 sets questionnaires were deemed usable and processed further for data analysis using SPSS.

\section{Findings}

\subsection{Normality Test and Cronbach's alpha Test}

For the current study, all variables were checked for normality of distribution. The distribution was symmetric. The quantile-normal plot of the residuals confirmed normality of errors. As shown in Figures 2 and 3, the residual versus fit plots confirmed linearity and equal variance. These results indicated that the data had no normality and linearity problems and could be analyzed further with SPSS. 


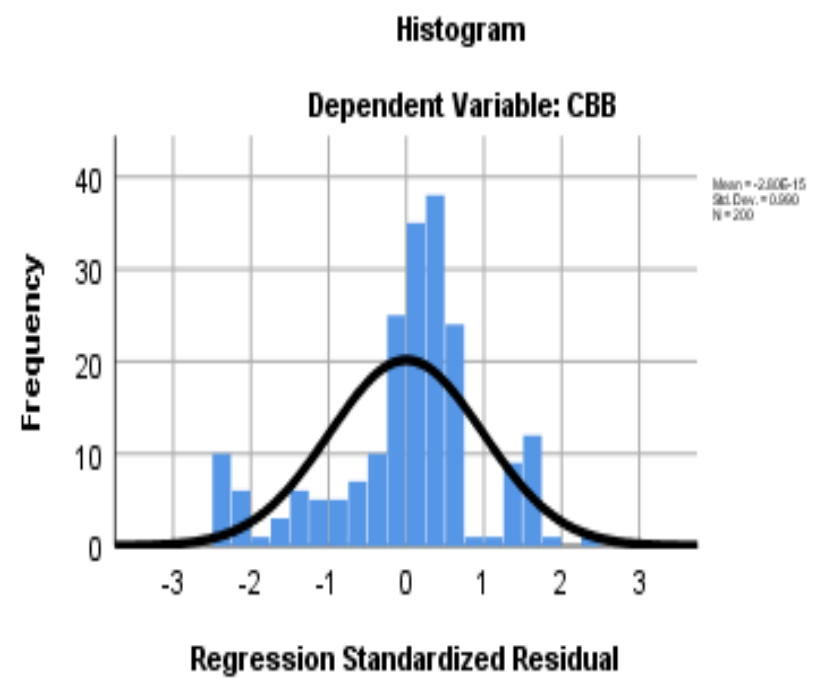

Figure 2. Histogram and normal probability plot

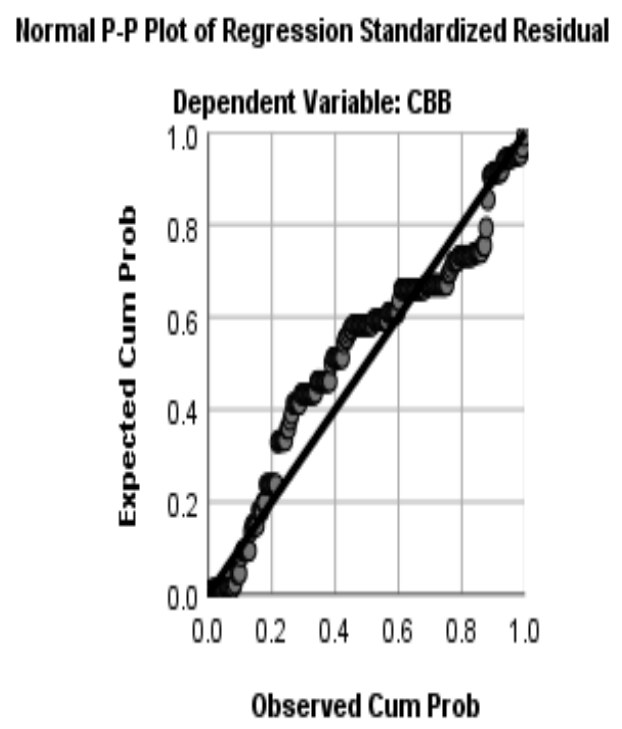

Figure 3. Normal probability plot

For the reliability test, all of the variables gave the Cronbach's alpha values greater than 0.9 , indicating their good reliability (John, 2003; Dennick \& Tavakol, 2011). Table 1 shows the reliability analysis of the variables presented in the study. A coefficient alpha ranging between 0.70 and 0.80 is interpreted as having a good reliability, while an alpha value between 0.60 and 0.70 indicates a fair reliability (John, 2003; Hair et al., 2010). Thus, all of the variables employed for this study were determined to be reliable.

Table 1. Result of reliability test

\begin{tabular}{lll}
\hline Variables & Number of items & Cronbach's alpha \\
\hline Environment factors & 5 & 0.953 \\
Service factors & 5 & 0.968 \\
Administrative factors & 5 & 0.949 \\
Transportation and location factors & 5 & 0.970 \\
Consumers buying behaviours in shopping malls & 5 & 0.976 \\
\hline
\end{tabular}




\subsection{Respondents' Demographic Characteristics}

The following Table 2: Gender and marital status of respondents presents the demographic characteristics (gender and marital status) of the respondents. For the gender of the respondents, 86 respondents $(43 \%)$ were male respondents and another 114 respondents $(57 \%)$ were female respondents. For the marital status, 94 respondents were unmarried (47\%), while 106 respondents were married (53\%).

Table 2. Gender and marital status of respondents

\begin{tabular}{llll}
\hline Gender & 86 male respondents (43\%) & 114 female respondents $(57 \%)$ & Total: 200 respondents \\
\hline Marital status & 94 respondents unmarried (47\%) & 106 respondents married (53\%) & Total: 200 respondents \\
\hline
\end{tabular}

\subsection{Multiple Regression Analysis}

Multiple regression was defined as a set of tools for studying the straight-line relationships among two or more variables (NCSS, Multiple Regression, 2015). In simpler terms, the general purpose of multiple regression aims to learn about the relationship between several independent variables and the dependent variable (Pearson, 1980). Multiple regression estimates the $\beta$ 's in the following equation:

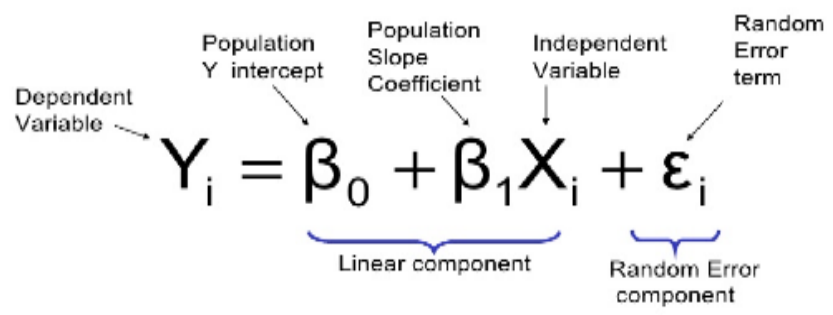

Figure 4. Multiple regression formula

Source: Samuels \& Gilchrist, 2014.

Hence, the tested results of multiple regression showed a coefficient that indicates the percentage of variation in dependent variable $(Y)$, which can be explained by the combination of all independent variables $(x)$. For instance, from the broader view, the $R$ value is the correlation between the predicted values and observed values of $Y . R^{2}$ value indicates the percentage of the variance in dependent variable is justified by the respective independent variables.

Based on the regression analysis (refer to Table 2), the $R^{2}$ value of each hypotheses are significantly greater the zero. Hence, based on the statement from Stare (1995), when $R^{2}$ value is greater than zero, indicating that the predictors are able to account for a significant amount of variances. Therefore, the regression model is significant.

Besides, in a narrower view, the Sig value or P value from multiple analysis are the determinants of significance. Prior studies suggested that if $\mathrm{P}>0.05$, it indicates a not significant relationship between variables. On the other hand, if $\mathrm{P}<0.05$, it indicates a significant relationship (Sekaran \& Bougie, 2016).

For this study, multiple regression analyses were conducted to examine the relationship between independent and dependent variables. According to West et al. (2003), multiple regression is regarded as an extension of basic linear regression. The purpose of conducting multiple regression analysis is for the prediction of the value of related variables that influence the dependent variable. The variables taken to predict the value of dependent variable are termed as independent variables. The regression coefficients display the relative significance of every single independent variable in the prediction of the dependent variable. The multiple regression formula for this study as follows:

where, for $\mathrm{i}=\mathrm{n}$ observations:

$$
\mathrm{Y}_{\mathrm{i}}=\beta_{0}+\beta_{1} \mathrm{X}_{\mathrm{i} 1}+\beta_{2} \mathrm{X}_{\mathrm{i} 2}+\ldots+\beta_{\mathrm{p}} \mathrm{X}_{\mathrm{ip}}+\epsilon
$$

$\mathrm{Y}_{\mathrm{i}}=$ Consumers' buying behaviours (dependent variable) 
$\mathrm{X}_{\mathrm{i} 1}=$ Environmental related factors $\left(\mathrm{X}_{\mathrm{i}}\right.$ are independent variables $)$

$\mathrm{X}_{\mathrm{i} 2}=$ Services related factors

$\mathrm{X}_{\mathrm{i} 3}=$ Administrative related factors

$\mathrm{X}_{\mathrm{i} 4}=$ Environmental related factors

$\beta_{0}=$ Y-intercept (constant term)

$\beta_{\mathrm{p}}=$ slope coefficients for each explanatory variable

$\epsilon=$ the model's error term (also known as the residuals)

Table 3 shows the result of the multiple regression analysis for this study.

Table 3. Coefficients of the regression analysis

\begin{tabular}{|c|c|c|c|c|c|c|}
\hline \multicolumn{7}{|c|}{ Coefficients $^{\mathrm{a}}$} \\
\hline \multirow[t]{2}{*}{ Model } & & \multicolumn{2}{|c|}{ Unstandardized Coefficients } & \multirow{2}{*}{$\begin{array}{l}\text { Standardized Coefficients } \\
\text { Beta }\end{array}$} & \multirow[t]{2}{*}{$-\mathrm{t}$} & \multirow[t]{2}{*}{ Sig. } \\
\hline & & $\mathrm{B}$ & Std. Error & & & \\
\hline \multirow[t]{5}{*}{1} & (Constant) & -2.081 & .411 & & -5.070 & .000 \\
\hline & $\mathrm{EF}$ & .273 & .076 & .241 & 3.593 & $.001^{* *}$ \\
\hline & SF & -.022 & .083 & -.018 & -.266 & .791 \\
\hline & $\mathrm{AF}$ & .061 & .094 & .054 & .652 & .515 \\
\hline & TALF & .777 & .083 & .720 & 9.315 & $.000^{* *}$ \\
\hline
\end{tabular}

Note. a. Dependent variable: $\mathrm{CBB} ; \mathrm{R}$-square $=0.967 ;$ Adjusted R-square value $=0.962 ; \mathrm{F}$ value $=1449.516 ; \mathrm{N}=200$.

EF: Environment factors, SF: Service factors, AF: Administrative factors, TALF: Transportation and location factors, CBB: Consumer's Buying Behavior in shopping malls.

Based on the results listed in Table 3, the F-statistics of the model was found to be significant. The adjusted R-squared value indicated that the regression model which included the environmental related factors, service-related factors, administrative related factors as well as transportation and location related factors could explain 96.7\% (0.967) variations in the dependent variable (consumer's buying behaviour in shopping malls). Furthermore, Table 3 also presents the $\mathrm{P}$ value analyzed for each of the variables, where $\mathrm{P}<0.05$ was considered to be significant. The results indicated that the environmental related factors as well as transportation and location related factors were found to be significant in the dependent variable, while the rest of the two variables, namely the service-related factors and administrative related factors were found to be insignificant in explaining consumer's buying behaviours in shopping malls.

The positively significant results obtained for the environmental related factors and transportation and location related factors towards the dependent variable indicate that the increase in these two variables would increase the consumer's buying behaviour in the malls. In addition, the table also revealed that the transportation and location factors had the highest beta coefficient value (0.720) indicating that those factors made the greatest contribution in explaining the dependent variable.

\section{Discussions of Results}

Hypotheses 1 (H1) postulated that the environmental relative factors, which include building structure, atmosphere, sounds and music and fragrance and smell have a positive relationship towards consumers' buying behaviours within shopping malls. The results from the regression analyses presented in Table 3 show that the $\mathrm{P}$ value for the environmental related factors as a variable is 0.001 , which is lower than the significant threshold of 0.05. This finding indicated that this variable is significant in influencing the consumers' buying behaviours within shopping malls. Therefore, the hypothesis 1 (H1) was accepted. This finding is supported by the earlier studies of Brengman et al. (2012) and Grimmer et al. (2016) that indicated that environmental related factors have positive effects on consumers' purchase behaviours.

Hypotheses 2 (H2) proposed that the services related factors, which are comprised of personal service, price, advertising and promotion have a positive relationship towards consumers' buying behaviours within shopping malls. Based on the results from the regression analyses in Table 2, the $\mathrm{P}$ value obtained for this variable was $\mathrm{P}=$ 0.791 which was greater than the significance threshold of 0.05 . This result indicated that the correlation between the variable and consumers' buying behaviours within shopping malls is not significant. Thus, the hypothesis 2 (H2) was rejected. This result is not concurrent with the earlier studies by Wong et al. (2012), Ala'Eddin (2012), Chebat et al. (2009) and Ahmed et al. (2007), as those studies stated that services related 
factors had a significant effect on consumers' buying behaviour within shopping malls. The difference between the previous studies and the current finding might be due to the time change factor and the change in the consumers' perception on purchase and services expected to be available in shopping malls. Consumers nowadays may expect more services in shopping malls that were not available before, such as car wash services, luggage storage and locker services, smartphone charging services, among others.

Hypotheses 3 (H3) argued that the administrative related factors comprised of tenant mix, anchor tenant and entertainment, have a positive relationship on consumers' buying behaviours within shopping malls. However, based on the results of the regression analyses presented in Table 2, hypothesis $3(\mathrm{H} 3)$ was rejected because the $\mathrm{P}$ value was 0.515 , which was greater than the significance threshold of 0.05 . This result shows that the variable was not significant in affecting the consumers' buying behaviours in shopping malls. This finding is not in agreement with the previous studies by Srivastava and Srinivasan (2010), Rajagopal (2009) and Eric et al. (2005) Those earlier studies found that the administrative related factors have a significant effect on consumers' buying behaviour in shopping malls. This seemingly contradictory finding might be due to the differences in the locations of the shopping malls where the studies were conducted. Another reason might arise from the consumers' preferences and cultural factors. Differences in the consumers' preferences and their cultural background can influence their choices of shops available in certain shopping malls.

Hypotheses 4 (H4) asserted that the transportation and location related factors, which consist of parking, catchment area and accessibility have positive influences on consumers' buying behaviours within the shopping malls. Based on the regression analyses in Table 2, the $\mathrm{P}$ value for the transportation and location related factors is 0.000 , which is lower than the significance threshold $(\mathrm{P}<0.05)$. This means that there is a significant relationship between transportation and location related factors and consumers' buying behaviours in shopping malls. Therefore, hypothesis 4 (H4) was accepted. This finding is supported by the earlier studies by Saber et al. (2017), Samiran et al. (2015), Eddin (2012) and Prybutok and Qin (2009). They found that transportation and location related factors have a significant effect on consumers' purchase behaviours in shopping malls.

\subsection{Contribution of the Research}

From a theoretical perspective, the contribution of this research lies in identifying how environmental related factors, services related factors, administrative related factors as well as transportation and location related factors impact on the consumers' purchase behaviours within shopping malls. This research has studied these related factors and developed a research framework to investigate the relationship between these four factors in influencing consumers' buying behaviours in the shopping malls. This study has extended the literature on consumers' behaviours and contributed to the schools of thoughts that help readers to understand how consumers behave.

From a practical perspective, the findings from this study are important for academicians and researchers, as well as practitioners, such as mall managers, mall tenants or store owners and shopping mall developers in obtaining consumers' information. From the perspectives of the academicians and researchers, the current findings can provide references for the factors that determine consumers' intentions and buying behaviours in shopping malls in Malaysia. Our study sets a ground work for other academicians and researchers to further explore possible roles of other factors in forming consumers' purchase intentions and patterns.

\section{Conclusion}

This research was aimed at determining the necessary inputs for gaining an insight into which factors would influence customers purchase behaviours so that our work would be a valuable instrument for the developers, managers and marketers to adapt their decisions to the changing environment and execute their plans effectively. Specifically, the results of our study indicated that environmental-related factors and transportation and location related factors served as the most influential factors on consumers' purchase behaviours within shopping malls. Shopping malls' managers are advised to consider such factors as key areas when considering strategies to improve the overall performance of their shopping malls.

The main target of any shopping malls' managers is always attracting new consumers and retaining current consumers in order to maintain and increase the sales and profit of their shopping malls. Identifying the factors that can influence consumers' behaviours would assist the tenants and shop owners of the shopping malls to develop new channels to contact and attract consumers. For example, provision of new services, such as online services, laptop or smartphone charging services, automated teller machine services (ATM) services and toll card top-up services to the consumers in their shop lots might help in achieving the ultimate goal of both shops and shopping malls, that is, to attract and retain consumers to the outlets in the shopping mall and promote their purchasing activities. 
Finally, the study carried out in this work was able to accomplish the research objectives of studying the important factors on the consumers' purchase behaviours in shopping malls in Malaysia. The results from this study have provided both theoretical and practical implications on what factors influence consumers' purchasing behaviours within shopping malls. Furthermore, the results of this study should provide useful insights to all relevant parties from managers of shopping malls and owners of shopping lots within those malls to improve on their shopping malls' performance, and to academicians to developing future research plans in the relevant field of study to expand our understanding of the subject.

\section{References}

Ahmed, Z. U., Ghingold, M., \& Dahari, Z. (2007). Malaysian Shopping Mall Behavior: An Exploratory Study. Asia Pacific Journal of Marketing and Logistic, 19(4), 331-348. https://doi.org/10.1108/13555850710827841

Ala'Eddin, M. K. A. (2012). Attractiveness Factors Influencing Shoppers' Satisfaction, Loyalty and Word of Mouth. International Journal of Business Administration, 3(3), 101-112. https://doi.org/10.5430/ijba.v3n6p101

Ashraf, G. M., Rizwan, M., Iqbal, A., \& Aslan, K. M. (2014). The Promotional Tools and Situational Factors' Impact on Consumer Buying Behaviour and Sales Promotion. Journal of Public Administration and Governance, 4(2), 179-201. https://doi.org/10.5296/jpag.v4i2.5844

Astono, C. (2014). The Effect of Shopping Mall's Attributes Toward Customer Satisfaction of ABC Mall and XYZ Mall. iBuss Management, 2(2), 99-106.

Badar, M. S., \& Irfan, M. (2018). Shopping Mall Services and Customer Purchase Intention Along with Demographics. Journal of Market-Focused Management, 1-17. Springer Verlag (Germany).

Bijandi, F., \& Sadeghi, T. (2011). The Effect of Shopping Mall Environment on Shopping Behaviour Under a Model. Middle-East Journal of Scientific Research, 8(3), 566-574.

Bilgehan, Y. C., \& Cihangir, Y. (2017). The Impact of Architectural Design of Shopping Malls on Consumer Behaviours. International Journal of Architecture \& Planning Received, 6(1), 142-157. https://doi.org/10.15320/ICONARP.2018.42

Brengman, M., Willems, K., \& Joye, Y. (2012). The Impact of in-store Greenery on Customers. Psychology \& Marketing, 29(11), 807-821. https://doi.org/10.1002/mar.20566

Breugelmans, E., \& Campo, K. (2011). Effectiveness of in-store Displays in a Virtual Store Environment. Journal of Retailing, 87(1), 75-89. https://doi.org/10.1016/j.jretai.2010.09.003

Cathy, H., Andrew, M. F., Grazyna, S., Gary, F., \& John, W. C. (2020). Shopping Experience Enjoyment: Impact on Customers' Repatronage Intentions and Gender Influence. Service Industries Journal, March, 1-47.

Chebat, J. C., Hedhli, K. E., \& Sirgy, M. J. (2009). How Does Shopper-based Mall Equity Generate Mall Loyalty? A Conceptual Model and Empirical Evidence. Journal of Retailing and Consumer Services, 16(1), 50-60. https://doi.org/10.1016/j.jretconser.2008.08.003

Dennick, R., \& Tavakol, M. (2011). Making Sense of Cronbach's alpha. International Journal of Medical Education, 2, 53-55. https://doi.org/10.5116/ijme.4dfb.8dfd

Eric, D. G., Pashigian, B. P., \& Prendergast, C. J. (2005). Contracts, Externalities and Incentives in Shopping Malls. Review of Economics and Statistics, 87(3), 411-422. https://doi.org/10.1162/0034653054638355

Familmaleki, M., Aghighi, A., \& Hamidi, K. (2015). Analyzing the Influence of Sales Promotion on Customer Purchasing Behavior. International Journal of Economics \& Management Sciences, 4(4), 1-6.

Farrag, D. A., El Sayed, I. M., \& Belk, W. R. (2010). Mall Shopping Motives and Activities: A Multimethod Approach. Journal of International Consumer Marketing, 22(2), 95-115. https://doi.org/10.1080/08961530903476113

Fatima, S., \& Lodhi, S. (2015). Impact of Advertisement on Buying Behaviours of the Consumers. International Journal of Management Sciences and Business Research, 4(10), 125-137.

Grimmer, M., Ashley, P. K., \& Miles, M. (2016). The Effect of Purchase Situation on Realized Pro-environmental Consumer Behaviour. Journal of Business Research, 89(5), 1582-1586. https://doi.org/10.1016/j.jbusres.2015.10.021

Gudonaviciene, R., \& Alijosiene, S. (2013). Influence of Shopping Centre Image Attributes on Customer Choices. 
Journal of Economics and Management, 18(3), 545-552. https://doi.org/10.5755/j01.em.18.3.5132

Gwowen, S. (2006). Exact Interval Estimation, Power Calculation and Sample Size Determination in Normal Correlation Analysis. Psychometrika, 71(3), 529-540. https://doi.org/10.1007/s11336-04-1221-6

Hanzaee, K. H., \& Javanbakht, A. (2013). The Effects of Shopping Environment on Consumption Emotions, Perceived Values and Behavioural Intentions. Management Science Letters, 3(9), 2501-2512. https://doi.org/10.5267/j.msl.2013.08.012

Hui, E. C. M., Zhang, P. H., \& Zheng. X. (2013). Facilities Management Service and Customer Satisfaction in Shopping Mall Sector. Journal of Facilities, 31(5/6), 194-207. https://doi.org/10.1108/02632771311307070

Hung, Y. Y., \& Sherry, Y. S. X. (2012). A Tenant-mix Model for Shopping Malls. European Journal of Marketing, 46(3/4), 524-541. https://doi.org/10.1108/03090561211202594

Irena, V. (2011). Atmospheric Music Fit as A Driver of Shopper Store Evaluations and Their Behavioural Responses. Journal of Applied Business Research, 24(2), 97-102. https://doi.org/10.19030/jabr.v24i2.1356

John, W. C. (2003). Research Design: Qualitative, Quantitative and Mixed Method Approaches. London: Sage Publications.

Kamel, E. H., Chebat, J. C., \& Sirgy, M. J. (2013). Shopping Well-being at The Mall: Construct, Antecedents, and Consequences. Journal of Business Research, 66(7), 856-863. https://doi.org/10.1016/j.jbusres.2011.06.011

Katrodia, A., Naude, M. J., \& Soni, S. (2018). Determinants of Shopping and Buying Behaviour: A Case at Durban Shopping Malls. African Journal of Business and Economic Research, 13(1), 221-243. https://doi.org/10.31920/Determinants_of_shopping_and_buying_behaviour

Kumar, H. H., \& John, S. F. (2014). A Study on Factors influencing Consumer Buying Behaviour in Cosmetic Products. International Journal of Scientific and Research Publications, 4(9), 1-6.

Maher, G. E., \& Ana, M. S. (2019). Entertainment me, I'll stay longer! The influence of types of entertainment on mall shoppers' emotions and behavior. Journal of Consumer Marketing, 37(1), 87-98. https://doi.org/10.1108/JCM-03-2019-3129

Makgopa, S. (2016). Determining Consumers' Reasons for Visiting Shopping Malls. Innovative Marketing, 12(2), 22-27. https://doi.org/10.21511/im.12(2).2016.03

Mariri, T., \& Chipunza, C. (2009). In-store Shopping Environment and Impulsive Buying. African Journal of Marketing Management, 1(4), 102-108.

NCSS. (2015). Multiple Regression. Retrieved May 05, 2020, from NCSS Statistical: https://www.ncss.com/software/ncss/regression-analysis-in-ncss/

Qin, H., \& Prybutok, V. R. (2009). Service Quality, Customer Satisfaction and Behavioral Intentions. International Journal of Quality and Service Science, 1(1), 78-95. https://doi.org/10.1108/17566690910945886

Rajagopal, P. (2009). Growing Shopping Malls and Behaviour of Urban Shoppers. Journal of Retail \& Leisure Property, 8(2), 99-118. https://doi.org/10.1057/rlp.2009.3

Saber, J. M., Lajis, N. A. A., Sandikau, E. N. R., Salim, A., Ibrahim, M. Z. F., \& Mustapha, R. I. P. (2017). The Effects of Parking Convenience Towards Customer Retention in Gurney Drive, Penang: A Preliminary Study. International Academic Research Journal of Social Science, 3(1), 1-5.

Samiran, M., Shukor, A. F. A., Saleh, H., \& Hasnan, N. (2015). The Relationship between Service Quality, Customer Satisfaction and Customer External Complaints Intentions in Commercial Parking Facilities in Klang Valley, Malaysia. International Journal of Science Environment, 4(3), 595-615.

Samuels, P., \& Gilchrist, M. (2014). Pearson Correlation. Birmingham: Birmingham City University.

Sebastian, E. H., \& Purwanegara, M. S. (2015). Influencing Factors and Attractiveness of Shopping Mall to Mall Behaviour of People in Jakarta. Journal of Business and Management, 3(1), 76-80.

Sekaran, U., \& Bougie, R. (2016). Research Method for Business: A Skill Building Approach (7th ed.). Chichester, West Sussex: John Wiley \& Sons.

Srivastava, R. K., \& Srinivasan, S. R. (2010). Creating the Futuristic Retail Experience Through Experiential Marketing: Is It Possible? Journal of Retail \& Leisure Property, 9(3), 193-199. https://doi.org/10.1057/rlp.2010.12

Stare, J. (1995). Some Properties of R2 in Ordinary Least Squares Regression. Retrieved May 01, 2020, from 
Methodology and Statistics: http://dk.fdv.uni-lj.si/MetodoloskiZvezki/Pdfs/Mz10Stare.pdf

West, S. G., Cohen, P., Aiken, L. S., \& Cohen, J. (2003). Applied Multiple Regression/Correlation Analysis for the Behavioral Sciences (3rd ed.). Mahwah, NJ: Lawrence Erlbaum Associates.

Wong, C. B., Ng, H. C., Wong, K., \& Wong, M. H. (2012). The Relationship between Shopping Mall Attributes, Customer Satisfaction and Positive Word of Mouth. Global Journal of Management and Business Research, $12(3), 49-62$.

\section{Copyrights}

Copyright for this article is retained by the author, with first publication rights granted to the journal.

This is an open-access article distributed under the terms and conditions of the Creative Commons Attribution license (http://creativecommons.org/licenses/by/4.0/). 